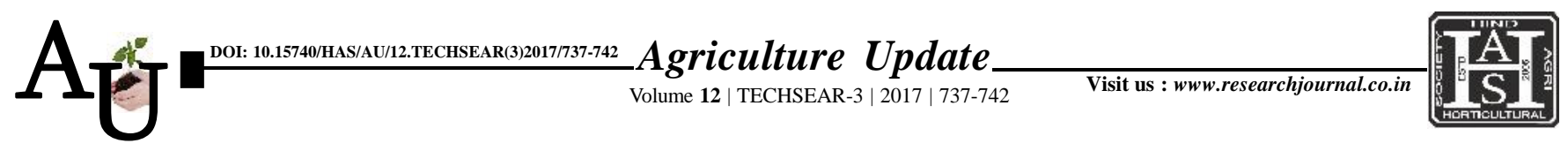

口 e ISSN-0976-6847

\title{
Research Article: Biorational and chemical management of defoliators on soybean
}

\section{A.A. MOTAPHALE, B.B. BHOSLE AND F.S. KHAN}

Article Chronicle :

Received :

10.07.2017;

Accepted :

25.07.2017

KEY WoRDs:

Defoliators, Soybean, Rynaxypyr, Chlorpyriphos, Emamectine benzoate

Author for correspondence :

\section{A.A. MOTAPHALE}

Department of Entomology, College of Agriculture, Vasantrao Naik Marathwada Krishi Vidyapeeth, PARBHANI (M.S.) INDIA

Email : dr.ashvini24@ gmail.com

See end of the article for authors' affiliations
SUMMARY : The present study was conducted during Kharif, 2010 and 2011, at Marathwada Agriculture University (MKV) Parbhani, Maharashtra, to study the biorationals insecticides for soybean defoliators. During this experiment per cent defoliation due to defoilators was ranged from 16.08 to 18.22 per cent and 9.69 to 17.93 per cent a day before the first spray and second spray, respectively. At 3 days after first and second sprays lowest per cent defoliation due to defoilators was found in Emamectin benzoate 5SG@ (10.11\%) and Indoxacarb 14.5\% (8.93\%), respectively. At 14 DAS, the defoliation was lowest in Emamectin benzoate 5SG@ (9.99\%) and Rynaxypyr 20 SC (8.02\%), respectively after first and second sprays.

How to cite this article : Motaphale, A.A., Bhosle, B.B. and Khan, F.S. (2017). Biorational and chemical management of defoliators on soybean. Agric. Update, 12(TECHSEAR-3) : 737-742; DOI: 10.15740/HAS/AU/ 12.TECHSEAR(3)2017/737-742. 